\title{
An Experimental Study of the Effects of Ceramic Composition on the Electrical and Thermal Properties of $\mathrm{Al} / \mathrm{SiC}$ Composites
}

\author{
Murat Aydin ${ }^{1 *}$ \\ 1*Erciyes University, Faculty of Aeronautics and Astronautics, Department of Aeronautical Engineering, Kayseri, Turkey, (ORCID: 0000-0003-3713-3029), \\ aydin@erciyes.edu.tr
}

(First received 27 May 2021 and in final form 15 August 2021)

(DOI: $10.31590 /$ ejosat.943506)

ATIF/REFERENCE: Aydın, M. (2021). An Experimental Study of the Effects of Ceramic Composition on the Electrical and Thermal Properties of Al/SiC Composites. European Journal of Science and Technology, (25), 721-726.

\begin{abstract}
$\mathrm{Al} / \mathrm{SiC}$ metal-matrix composites were investigated through Differential Thermal Analysis device as a function of volume fraction of $\mathrm{SiC}$ particles and sample temperature ranging $273 \mathrm{~K}$ to $373 \mathrm{~K}$. It was found that electrical resistivity increased with increasing sample temperature and volume fraction of $\mathrm{SiC}$. In contrast to electrical resistivity, electrical conductivity decreased with increasing sample temperature and volume fraction of SiC. Electrical conductivity decreased from $1,8 \times 10^{7} 1 / \mathrm{ohm} . \mathrm{m}$ to $2 \times 10^{6} 1 / \mathrm{ohm}$.m as the volume fraction of $\mathrm{SiC}$ increased to $60 \%$. On the other hand, thermal conductivity decreased with increasing volume fraction of SiC particles, while being almost insensitive to temperature change between $273 \mathrm{~K}$ to $373 \mathrm{~K}$. Thermal conductivity decreased from $120 \mathrm{~W} / \mathrm{mK}$ to 10 $\mathrm{W} / \mathrm{mK}$ as the volume fraction of $\mathrm{SiC}$ increased to $60 \%$.
\end{abstract}

Keywords: Metal-Matrix composites, Electrical conductivity, Thermal conductivity, Al/SiC

\section{Al/SiC Kompozit Malzemelerde Seramik Bileşenin Hacimsel Oranının Elektriksel ve Isıl Özellikler Üzerindeki Etkilerinin Deneysel İncelemesi}

Öz

$\mathrm{Bu}$ çalışmada $\mathrm{Al} / \mathrm{SiC}$ metal matris kompozit malzemelerde, seramik bileşenin hacimsel değişiminin elektriksel ve 1sıl iletkenlik üzerindeki etkileri 273K- 373K sıcaklık aralığında, deneysel olarak ile incelenmiştir. Test sonuçlarında, sıcaklığın ve seramik bileşenin hacimsel oranının artmasıyla elektriksel direncin arttığı ve elektriksel iletkenliğin azaldığı görülmüştür. Seramik bileşenin

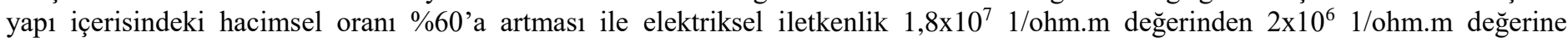
düşmüştür. Ayrıca metal matris kompozit malzemelerde seramik bileşenin artması ile termal iletkenliği azalmış olup 273 ila $373 \mathrm{~K}$ arasındaki sıcaklık değişiminin ısıl iletkenlik üzerinde önemli bir etkisi olmamıştır. Seramik bileşenin hacimsel oranının \%60’a çıkması ile 1 sıl iletkenlik $120 \mathrm{~W} / \mathrm{mK}$ değerinden $10 \mathrm{~W} / \mathrm{mK}$ değerine düşmüştür.

Anahtar Kelimeler: Metal-Matris kompozitler, Elektriksel iletkenlik, Isıl iletkenlik, Al/SiC

\footnotetext{
*Corresponding Author: aydin@erciyes.edu.tr
} 


\section{Introduction}

Metal matrix composites (MMCs) are class of metal that combines both metal and another material to improve current performance. These composites can be classified based on their matrix metals such as Cu-based, Al-based, Mg-based etc. while they can be named based on reinforcement type such as fiber reinforced, whisker reinforced, particle reinforced etc. (Mortensen \& Llorca, 2010). MMCs have been attractive engineering materials due to many factors including having tailorable properties (e.g. Elastic modulus, strength etc.), being the only way to introduce ceramic particles such as carbide and oxide into metals for better performances for harsh environments. These advantages have led researches on MMCs to date starting from the late 1980s (Evans et al., 2003; Mortensen \& Llorca, 2010).

Amongst MMCs, Al-matrix composites have been extensively studied due to low density and high ductility of Al. Addition of ceramic particles to Al metal generally increased mechanical properties in addition to corrosion and wear resistance of pure Al (Sahin \& Murphy, 1996; Torres et al., 2002). $\mathrm{Al}_{2} \mathrm{O}_{3}$ and $\mathrm{SiC}$ have been the most widely used reinforcements introduced into $\mathrm{Al}$ to form Al-matrix MMCs (Lavernia et al., 1995). Owing to low cost and better mechanical properties in addition to high temperature stability (Khadem et al., 2011), SiC has been more attractive as a reinforcement material (Ünlü, 2008; Xiong et al., 2011). Effects of SiC particles on the mechanical properties of $\mathrm{Al} / \mathrm{SiC}$ MMCs have been extensively studied. It was found that strength and hardness levels increased with increasing volume fraction of $\mathrm{SiC}$, while impact toughness is inversely proportional (Ozben et al., 2008). It was also shown that impact properties of $\mathrm{Al} / \mathrm{SiC} \mathrm{MMC}$ are strongly affected by matrix-reinforcement bonding and particle cracking (Ozden et al., 2007). Aging process was found to be effective on the fatigue life of $\mathrm{Al} / \mathrm{SiC}$ MMCs. It was observed that peak aged MMCs showed less fatigue life degradation compared to under-aged conditions (Srivatsan et al., 2005). Effect of particle clustering and random distribution of $\mathrm{SiC}$ studies showed that microstructures having clustered particles experienced more extensive particle fracture compared to the microstructures with randomly distributed $\mathrm{SiC}$ particles under tensile loading (Peng \& Fuguo, 2010).

Besides mechanical properties, thermal and electrical properties have utmost importance for engineering applications pointing to thermal and electrical management. One of these engineering applications is electronic packaging owing to lightweight, low cost and good physical properties (Lee, 2000). Additionally, pliable manufacturing creates advantages on tailoring physical properties such as thermal and electrical conductivity. Up to date, many electronic packaging applications have been realized using MMCs (Guo et al., 2014; Zweben, 1992) such as microwave housing with $\mathrm{Al} / \mathrm{SiC}$. For tailorable thermal and electrical properties, it is critical to control volume fraction of $\mathrm{SiC}$ particles in the microstructure. Because these properties are highly sensitive to the volume fraction of ceramic and metal in an MMC. In general, thermal, and electrical conductivity values of $\mathrm{Al} / \mathrm{SiC}$ MMCs decreased with increasing volume fraction of $\mathrm{SiC}$ particles (Lee, 2000; Weber et al., 2010). High volume fraction (e.g. > 50\%) of $\mathrm{SiC}$ particles is important to reduce the coefficient of thermal expansion (CTE) for having a material that has comparable thermal properties with conventional thermal controlling materials such as alumina and semiconductors (Lee, 2000).

This study aims to contribute to the research literature on the thermal and electrical properties of $\mathrm{Al} / \mathrm{SiC}$ metal matrix composites. Al/SiC MMCs with volume fractions of ceramic particles ranging from $0-60 \%$. Electrical and thermal properties were characterized through Differential Thermal Analysis. It was found that electrical resistivity increased with increasing volume fraction of $\mathrm{SiC}$. On the other hand, electrical and thermal conductivity values decreased with increasing volume fraction of $\mathrm{SiC}$ particles. A maximum electrical conductivity of $1,8 \times 107$ $1 / \mathrm{ohm} . \mathrm{m}$ was achieved for pure $\mathrm{Al}$, where the maximum thermal conductivity was $120 \mathrm{~W} / \mathrm{mK}$. As the volume fraction of $\mathrm{SiC}$ increased to $60 \%$, the electrical conductivity and thermal conductivity values decreased to $2 \times 106$ 1/ohm.m and 10 $\mathrm{W} / \mathrm{mK}$, respectively. Electrical conductivity decreased with increasing sample temperature, while a slight increase was observed in thermal conductivity with increasing temperature.

\section{Experimental Procedure}

The MMC composites were produced by a powder stackinghot pressing method using $\mathrm{Al}$ and $\mathrm{SiC}$ powders. Maximum particle diameter of Al spherical powders was $44 \mu \mathrm{m}$, where maximum powder diameter of spherical $\mathrm{SiC}$ powders was $10 \mu \mathrm{m}$ The metal and ceramic powders were mechanically blended for 3 hours to obtain a homogeneous mixture followed by pouring the mixture into sintering mold. The sintering process was conducted at $600^{\circ} \mathrm{C}$ under $100 \mathrm{MPa}$ for $90 \mathrm{~min}$. A vacuum and argon atmosphere were used to prevent oxidation during sintering. Figure 1 shows the processing steps of Al-SiC metal matrix composites.

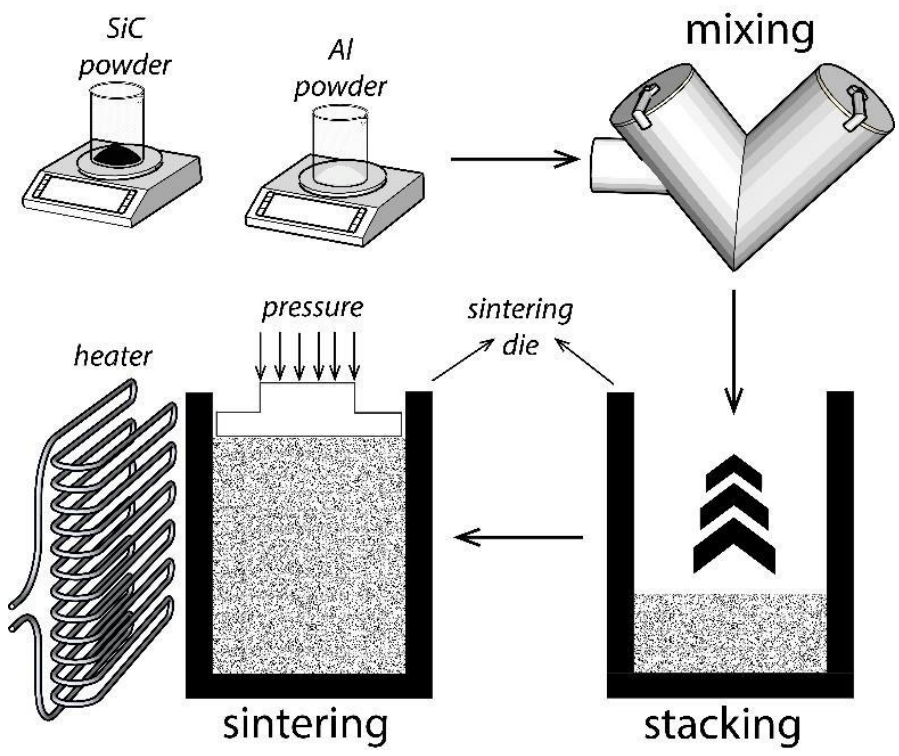

Figure 1. The production process of metal matrix composites by powder stacking hot pressing technique.

The high temperature phase analysis of $\mathrm{Al}-\mathrm{SiC}$ composites were made by using the Perkin Elmer Diamond Differential Thermal Analysis device. All thermal analysis was made at the heating rate of $20 \mathrm{~K} / \mathrm{min}$. in pure nitrogen atmosphere. The electrical resistivity vs. temperature was carried out for the samples using (CRYO Industries of America Model No: REF2261-202HT) with $4 \mathrm{~K} / \mathrm{min}$ heating rate under vacuum between $273 \mathrm{~K}$ and $373 \mathrm{~K}$ temperature range. 


\section{Results and Discussion}

Figure 2 shows microstructures of $\mathrm{Al} / \mathrm{SiC}$ composites as a function of volume fraction of $\mathrm{SiC}$. It is clear that as the volume fraction of $\mathrm{SiC}$ increases, white areas ( $\mathrm{Al}$ matrix) decrease compared to dark areas ( $\mathrm{SiC}$ particles). $\mathrm{Al}$ and $\mathrm{SiC}$ areas are marked on the image.

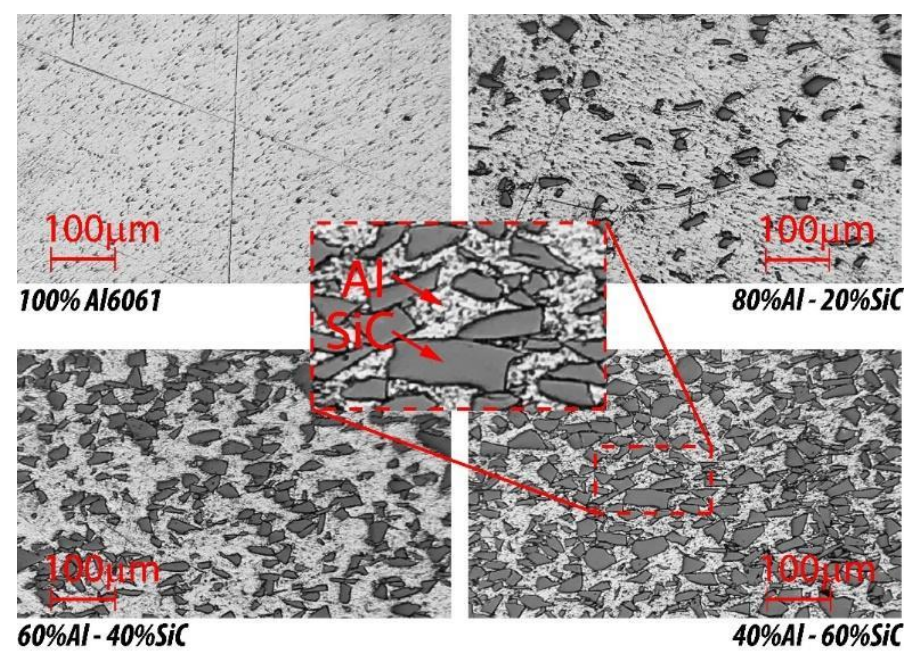

Figure 2. Microstructure of Al/SiC composites as a function of $\mathrm{SiC}$

Figure 3 shows differential thermal analysis results of all composite materials. The samples were thermally cycled under zero stress between temperatures of 293 and 1073K. It is evident that aluminum phase conversion value decreased as the volume fraction of $\mathrm{SiC}$ particles increased. When the $\mathrm{SiC}$ ratio was $60 \%$, it was determined that there were two phase transformations in succession. The first of these two-phase transformations was the eutectoid $\mathrm{Si}$ phase transformation and the other phase transformation was a phase transformation from solid to liquid (Ravi et al., 2007; B. Singh et al., 2013; V. K. Singh et al., 2014).

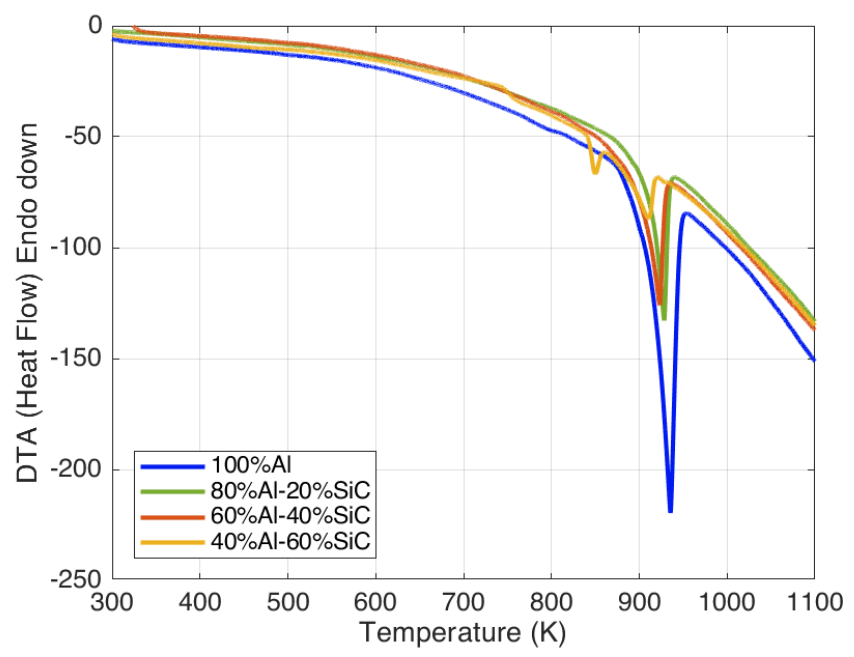

Figure 3. DTA termograms of Al/SiC composite materials

Table 1 shows the melting temperature and phase transformation enthalpy values of the $\mathrm{Al} / \mathrm{SiC}$ composites related to chemical compositions. It is clear that the melting temperatures and phase transformation enthalpy values decreased with increasing volume fraction of $\mathrm{SiC}$ particles. The decrease of the melting temperatures with increasing SiC content is in good agreement with the literature. Singh et al. also saw that the value of melting temperature decreased with the contribution of $\mathrm{SiC}$ in Al-SiC composite (V. K. Singh et al., 2014).

The enthalpy values also decreased with increasing SiC. This might be due to the decrease in $\mathrm{Al}$ content in the composites. Since the only phase transformable material is $\mathrm{Al}$ in the studied temperature range, the phase transformation enthalpy is directly linked to the amount of $\mathrm{Al}$ metal in the composites. Decreased $\mathrm{Al}$ content resulted in a decrease in the enthalpy values.

Table 1. DTA results of Al/SiC composite materials.

\begin{tabular}{lcc}
\hline Composition & Melting point $(\boldsymbol{K})$ & Enthalpy $(\boldsymbol{\mu V . s} / \mathbf{m g})$ \\
\hline$\% 100 \mathrm{Al}$ & 935.1 & 374.0 \\
$\% 80 \mathrm{Al}-\% 20 \mathrm{SiC}$ & 928.3 & 312.0 \\
$\% 60 \mathrm{Al}-\% 40 \mathrm{SiC}$ & 923.6 & 218.3 \\
$\% 40 \mathrm{Al}-\% 60 \mathrm{SiC}$ & 909.7 & 90.6 \\
\hline
\end{tabular}

Figure 4 shows electrical resistivity values of $\mathrm{Al} / \mathrm{SiC}$ composites as a function of temperature ranging $273 \mathrm{~K}$ to $373 \mathrm{~K}$. Electrical resistivity $(\rho)$ value was measured directly by using a cryostat system. The electrical resistivity value increases with increasing $\mathrm{SiC}$ ratio in the $\mathrm{Al}-\mathrm{SiC}$ composite. This increase has gained significant momentum with the $\mathrm{SiC}$ ratio being a matrix. If we examine the variation of the electrical resistance with temperature for each composite, it was concluded that the resistance value between $273 \mathrm{~K}$ and $373 \mathrm{~K}$ did not vary significantly.

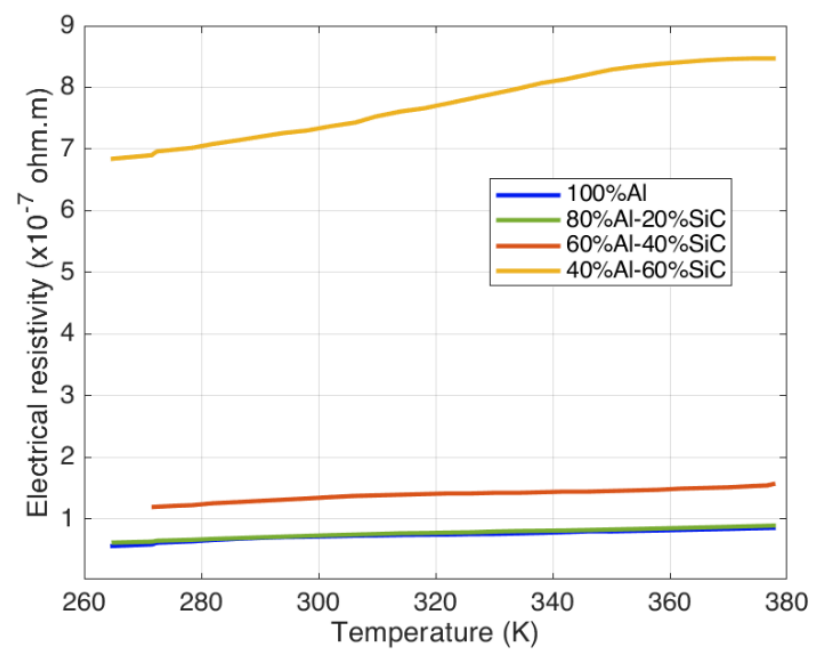

Figure 4. Electrical resistivity of Al/SiC composites as a function of temperature.

Figure 5 shows the electrical conductivity change of $\mathrm{Al} / \mathrm{SiC}$ composites by temperature. The electrical conductivity $(\sigma)$ value was calculated by the formula $(\sigma=1 / \rho)$. In contrast to the electrical resistance of composites, their electrical conductivity and thermal conductivity have been shown to decrease with increasing $\mathrm{SiC}$ contribution. Since the $\mathrm{SiC}$ particles are nonconducting parts of the $\mathrm{Al} / \mathrm{SiC}$ composites, the dependence of the electrical conductivity on the volume fraction of $\mathrm{SiC}$ ceramic particles can be explained based on the differential effective medium scheme, which is widely used in modeling of conductivity of metal matrix composites reinforced by nonconductive particles such as SiC (Weber et al., 2003). Differential effective medium scheme can be to explain the 
relationship between volume fraction of matrix and electrical conductivity as follows:

$$
\sigma_{c}=\sigma_{m} V_{m}^{n}
$$

where $\sigma_{\mathrm{c}}$ is conductivity of composite, $\sigma_{\mathrm{m}}$ is conductivity of matrix, $V_{m}$ is volume fraction of matrix and $n$ is a parameter related to particle shape. Therefore, as the volume fraction of metal matrix increases in a composite, electrical conductivity increases. In other words, electrical conductivity decreases as the volume fraction of non-conductive reinforcement increases based on the formula above.

As mentioned above, electrical resistivity is strongly dependent on temperature change in metallic materials. Electrical resistivity increases with increasing sample temperature. This fact is usually expressed by (Kahveci et al., 2019):

$$
\rho_{s}=\rho_{o}\left[1+\alpha\left(T-T_{o}\right]\right.
$$

where $\rho_{\mathrm{s}}$ is electrical resistivity at temperature T, $\rho_{\mathrm{o}}$ is electrical resistivity at room temperature, $\alpha$ is electrical resistivity coefficient and $\mathrm{T}_{\mathrm{o}}$ is room temperature. Based on the formula, electrical resistivity increases with increasing temperature as shown in Figure 4. Since the thermal conductivity is calculated by taking the inverse of electrical resistivity, it is expected that electrical conductivity decreased by increasing temperature.

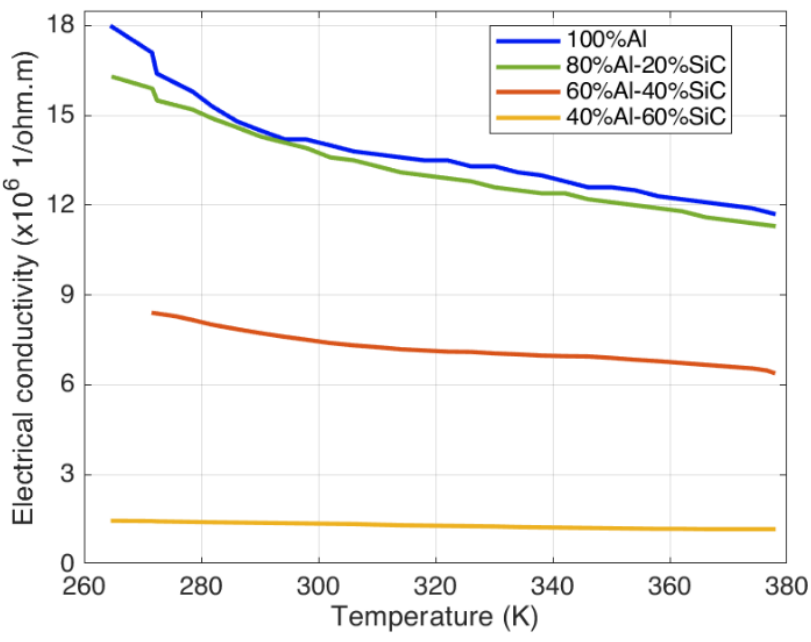

Figure 5. Electrical conductivity of Al/SiC composites as a function of temperature.

Figure 6 shows thermal conductivity values as a function of temperature in $\mathrm{Al} / \mathrm{SiC}$ composites. The thermal conductivity values were calculated using Wiedemann-Franz law.

Wiedemann-Franz law is a law derived from the kinetic theory of gases, but it is applied for solid materials. According to this law, there is a relation between thermal conductivity and electrical conductivity as follows.

$$
\sigma=\frac{K}{L T}
$$

In this equation, $\mathrm{K}$ is the thermal conductivity of the sample, $\mathrm{L}$ is Lorenz number, $\mathrm{T}$ is the temperature in kelvin and $\sigma$ is the electrical conductivity of that sample. $\mathrm{L}$ is almost equal to 2.44x10-7 W $\Omega / \mathrm{K} 2$ for metals and semiconductors (Bevington \&
Han Kim, 1979; Krishnamachar, 2018; Patel et al., 2013; Yi et al., 2020).

It is clear that thermal conductivity values decreased by increasing volume fraction of $\mathrm{SiC}$ particles. In contrast to electrical conductivity results in Figure 6, thermal conductivity values were not generally sensitive to change of sample temperature.

It is known that heat is conducted through two main mechanisms, which are electrons mobility and phonon vibrations (Polat et al., 2019). In metals, electrons mobility is more dominant mechanism in heat conduction compared to phonon vibrations. In ceramics, the responsible mechanism for heat conduction is phonon vibration, since there are no free electrons to conduct heat from one place to another. On the other hand, ceramic materials are known to have lower thermal conductivity compared to metals, due to scattering of phonon vibrations in ceramics (Salaway et al., 2008). Thus, thermal conductivity values decreased with increasing volume fraction of $\mathrm{SiC}$ in the current $\mathrm{Al} / \mathrm{SiC}$ composites.

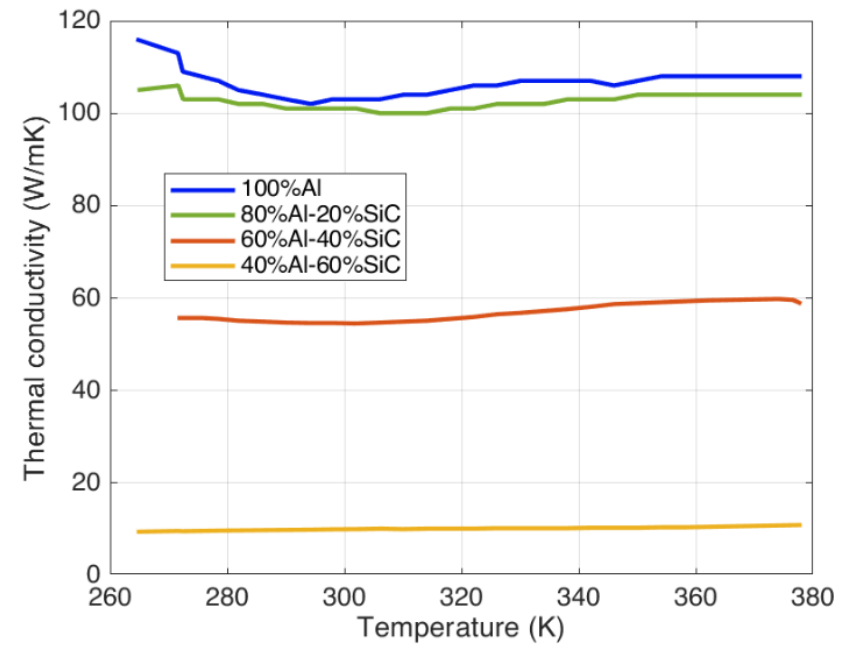

Figure 6. Thermal conductivity of Al/SiC composites as a function of temperature.

On the other hand, it's previously reported that an increase in the volume fraction of porosity in metal matrix composites resulted in a decrease of thermal conductivity values. The volume fraction of voids is expected to increase with increasing volume fraction of $\mathrm{SiC}$ particles in the current $\mathrm{Al} / \mathrm{SiC}$ composites. Since none of the two heat conductive mechanisms, electrons mobility or phonon vibration, operates in voids, an increase of voids in microstructure results in a decrease in thermal conductivity values in $\mathrm{Al} / \mathrm{SiC}$ composites as previously observed (Cem Okumus et al., 2012). The relationship between porosity and thermal conductivity can be expressed by the following formula (Kobayashi et al., 2013).

$$
k_{m}^{p}=k_{m}\left[\frac{1-V_{p}}{1+V_{p}}\right]
$$

where $k_{m}^{p}$ and $k_{m}$ are thermal conductivities of matrix with and without porosity, respectively and $\mathrm{Vp}$ is the volume fraction of porosity in microstructure. As clear from the formula, as the volume fraction of porosity increases in a microstructure of composite, the thermal conductivity of the matrix decreases. Additionally, the occurrence of interface reactions with increasing $\mathrm{SiC}$ ratio may cause the thermal conductivity value to 
decrease with the $\mathrm{SiC}$ additive in $\mathrm{Al}-\mathrm{SiC}$ composites. The same reasons are thought to be the factors that decrease the electrical conductivity of the composite and increase the electrical resistance.

\section{Conclusions}

Differential Thermal Analysis method was used to characterize thermal and electrical properties of $\mathrm{Al} / \mathrm{SiC}$ composites with volume fraction of $\mathrm{SiC}$ particles reaching to $60 \%$ as a function temperature ranging $273 \mathrm{~K}$ to $373 \mathrm{~K}$. Based on the experimental results, it was observed that electrical resistivity increased with increasing sample temperature and volume fraction of $\mathrm{SiC}$ ceramic particles. On the contrary, electrical conductivity was found to be decreased with increasing sample temperature and volume fraction of $\mathrm{SiC}$. Electrical conductivity decreased to $2 \times 106$ 1/ohm.m as the volume fraction of $\mathrm{SiC}$ increased to $60 \%$. Thermal conductivity was observed to be decreased with increasing volume fraction of $\mathrm{SiC}$ ceramic particles and was nearly not dependent on temperature change between $273 \mathrm{~K}$ to $373 \mathrm{~K}$. A minimum thermal conductivity of $10 \mathrm{~W} / \mathrm{mK}$ was observed as the volume fraction of $\mathrm{SiC}$ was $60 \%$.

\section{References}

B. Torres, M. Lieblich, J. Ibáñez, \& A. García-Escorial (2002). Mechanical properties of some PM aluminide and silicide reinforced 2124 aluminium matrix composites. Scripta Materialia, 47(1), 45-49.

Bekir Sadık Ünlü (2008). Investigation of tribological and mechanical properties Al2O3-SiC reinforced Al composites manufactured by casting or $\mathrm{P} / \mathrm{M}$ method. Materials \& Design, 29(10), 2002-2008.

Bevington, R., \& Han Kim (1979). Thermophysical Properties of Ag-CdO Composite Materials. IEEE Transactions on Components, Hybrids, and Manufacturing Technology, 2(1), 46-51.

Bowen Xiong, Zhifeng $\mathrm{Xu}$, Qingsong Yan, Baiping $\mathrm{Lu}$, \& Changchun Cai (2011). Effects of SiC volume fraction and aluminum particulate size on interfacial reactions in $\mathrm{SiC}$ nanoparticulate reinforced aluminum matrix composites. Journal of Alloys and Compounds, 509(4), 1187-1191.

Cem OKUMUS, S., Aslan, S., Karslioglu, R., Gultekin, D., \& Akbulut, H. (2012). Thermal Expansion and Thermal Conductivity Behaviors of Al-Si/SiC/graphite Hybrid Metal Matrix Composites (MMCs). Materials Science, 18(4), 341346.

Evans, A., San Marchi, C., \& Mortensen, A. (2003). Metal Matrix Composites in Industry An Introduction and a Survey / by Alexander Evans, Christopher San Marchi, Andreas Mortensen.. Springer US : Imprint: Springer

Hojoon Yi, Ji Yeon Kim, Hamza Zad Gul, Seungsu Kang, Giheon Kim, Eunji Sim, Hyunjin Ji, Jungwon Kim, Young Chul Choi, Won Seok Kim, \& Seong Chu Lim (2020). Wiedemann-Franz law of $\mathrm{Cu}$-coated carbon fiber. Carbon, 162, 339-345.

K Srinivas, M S Bhagyashekar, \& B G Darshan (2018). Journal of Polymer \& Composites Effect of Fillers on Electrical Conductivity of Epoxy Composites, 6(3).

Kahveci, O., Çadirli, E., Arı, M., Tecer, H., \& Gündüz, M. (2019). Measurement and Prediction of the Thermal and Electrical Conductivity of Al-Zr Overhead Line Conductors at Elevated Temperatures. Materials Research, 22(1), e20180513.

L. Weber, J. Dorn, \& A. Mortensen (2003). On the electrical conductivity of metal matrix composites containing high volume fractions of non-conducting inclusions. Acta Materialia, 51(11), 3199-3211.

Lavernia, E., Perez, R., \& Zhang, J. (1995). Damping behavior of discontinuously reinforced ai alloy metal-matrix composites. Metallurgical and Materials Transactions A, 26(11), 2803-2818.

Lee, H., Jeon, K., Kim, H., \& Hong, S. (2000). Fabrication process and thermal properties of $\mathrm{SiCp} / \mathrm{Al}$ metal matrix composites for electronic packaging applications. Journal of Materials Science, 35(24), 6231-6236.

Manish Patel, V.V. Bhanu Prasad, \& Vikram Jayaram (2013). Heat conduction mechanisms in hot pressed $\mathrm{ZrB} 2$ and $\mathrm{ZrB} 2-\mathrm{SiC}$ composites. Journal of the European Ceramic Society, 33(10), 1615-1624.

Ming-hai GUO, Jun-you LIU, \& Yan-xia LI (2014). Microstructure and properties of $\mathrm{SiCp} / \mathrm{Al}$ electronic packaging shell produced by liquid-solid separation. Transactions of Nonferrous Metals Society of China, 24(4), 1039-1045.

Mortensen, A., \& Llorca, J. (2010). Metal Matrix Composites. Annual Review of Materials Research, 40(1), 243-270.

Ravi, K., Pillai, R., Pai, B., \& Chakraborty, M. (2007). A Novel Approach for Extracting and Characterizing Interfacial Reaction Products in Al-SiCpComposites. Metallurgical and Materials Transactions A, 38(7), 1666-1670.

S.A. Khadem, S. Nategh, \& H. Yoozbashizadeh (2011). Structural and morphological evaluation of $\mathrm{Al}-5 \mathrm{vol} . \% \mathrm{SiC}$ nanocomposite powder produced by mechanical milling. Journal of Alloys and Compounds, 509(5), 2221-2226.

Safa Polat, Yavuz Sun, Engin Çevik, \& Hendrik Colijn (2019). Evaluation of thermal conductivity of GNPs-doped B4C/Al$\mathrm{Si}$ composites in terms of interface interaction and electron mobility. Diamond and Related Materials, 98, 107457.

Sahin, Y., \& Murphy, S. (1996). The effect of fibre orientation of the dry sliding wear of borsic-reinforced 2014 aluminium alloy. Journal of Materials Science, 31(20), 5399-5407.

Salaway, R., Hopkins, P., Norris, P., \& Stevens, R. (2008). Phonon Contribution to Thermal Boundary Conductance at Metal Interfaces Using Embedded Atom Method Simulations. International Journal of Thermophysics, 29(6), 1987-1996.

Sedat Ozden, Recep Ekici, \& Fehmi Nair (2007). Investigation of impact behaviour of aluminium based $\mathrm{SiC}$ particle reinforced metal-matrix composites. Composites Part A: Applied Science and Manufacturing, 38(2), 484-494.

Singh, B., Kumar, J., \& Kumar, S. (2013). Investigating the Influence of Process Parameters of ZNC EDM on Machinability of A6061/10\\% SiC Composite. Advances in Materials Science and Engineering, 2013, 173427.

Singh, V., Chauhan, S., Gope, P., \& Chaudhary, A. (2014). Enhancement of Wettability of Aluminum Based Silicon Carbide Reinforced Particulate Metal Matrix Composite. High Temperature Materials and Processes, 34(2): p. 163170.

T.S. Srivatsan, Meslet Al-Hajri, \& V.K. Vasudevan (2005). Cyclic plastic strain response and fracture behavior of 2009 aluminum alloy metal-matrix composite. International Journal of Fatigue, 27(4), 357-371. 
Tamer Ozben, Erol Kilickap, \& Orhan Çakır (2008). Investigation of mechanical and machinability properties of $\mathrm{SiC}$ particle reinforced Al-MMC. Journal of Materials Processing Technology, 198(1), 220-225.

Tomohiro Kobayashi, Katsumi Yoshida, \& Toyohiko Yano (2013). Microstructure, mechanical and thermal properties of $\mathrm{B} 4 \mathrm{C} / \mathrm{CNT}$ composites with $\mathrm{Al}$ additive. Journal of Nuclear Materials, 440(1), 524-529.

Weber, L., Sinicco, G., \& Molina, J. (2010). Influence of processing route on electrical and thermal conductivity of $\mathrm{Al} / \mathrm{SiC}$ composites with bimodal particle distribution. Journal of Materials Science, 45(8), 2203-2209.

Zhang Peng, \& Li Fuguo (2010). Effects of Particle Clustering on the Flow Behavior of SiC Particle Reinforced Al Metal Matrix Composites. Rare Metal Materials and Engineering, 39(9), 1525-1531.

Zweben, C. (1992). Metal-matrix composites for electronic packaging. JOM, 44(7), 15-23. 